\title{
8. Conclusions to National Courts and Preliminary References to the Court of Justice
}

\section{KEY FINDINGS}

This book has attempted to answer four questions relating to the different phases in the interaction between national courts and the ECJ in the context of the preliminary ruling procedure: question, answer and follow-up. The fourth question concerned the relationship between the answer (ie, the satisfaction of national judges with their interaction with the ECJ and the answers) and the question (ie, the motives of judges (not) to refer).

\subsection{Question: National Judges' Motives (Not) to Refer}

With respect to the first question on the decision to submit a question to the ECJ, this book has highlighted the intricate interplay of various motives and factors that affect judicial decision making. These motives and factors can be placed at different levels of analysis: the micro, meso and macro levels (see Table 8.1). ${ }^{1}$

This book's findings show that legal formalist explanations deserve more recognition in the social science literature, because judges are simply required to follow and apply legal norms. Much of the literature seems to overlook the fact that many references deal with rather unexciting legal details about customs tariffs or undefined terms in EU legislation, instead of politically sensitive national laws and policies that conflict with EU law. Chapter 2 revealed that some courts adopt a legal formalist approach and faithfully apply Article 267 TFEU while abiding strictly by the CILFIT exceptions - that is, the Civil and Tax Chambers of the Dutch Supreme Court and the Irish Supreme Court, Court of Appeal and High Court. Good illustrations include the customs classification cases of Sonos and Sprengen: the Dutch Tax Chamber decided to refer questions even though the two courts of first instance and the AG were

\footnotetext{
Dyevre 2016, 11.
} 
Table 8.1 Overview of the different levels of analysis and relevant motives and factors

\begin{tabular}{|c|c|}
\hline Level of analysis & Variables \\
\hline Macro level & $\begin{array}{l}\text { - Independence of the judiciary (Chapter 3, sections } 2.3 \text { and 3.3; and Chapter } 4 \text {, } \\
\text { section 3). } \\
\text { - (De)centralized organization of the judiciary (recruitment, appointment and pro- } \\
\text { motion) (Chapter 3, section } 2.3 \text { ). } \\
\text { - Position of EU law in the national legal order (Chapter 1, section 4.1). } \\
\text { - Adversarial/inquisitorial nature of the legal system (Chapter 3, section 4). } \\
\text { - Culture of judicial review (Chapter 4, section 2). }\end{array}$ \\
\hline Meso level & $\begin{array}{l}\text { - Institutional court-related factors (coordination, case management, capacity) } \\
\text { (Chapter 3, section 3). } \\
\text { - Level of specialization and culture within courts (Chapter 3, section 2.2). } \\
\text { - Availability of EU law training and education in (post) university curricula } \\
\text { (Chapter 3, section } 2.2 \text { ). } \\
\text { - Opportunity structures for parties: court fees, the availability of legal aid, require- } \\
\text { ments as to representation by a lawyer, national standing rules (Chapter 3, section } \\
\text { 4). } \\
\text { - Position in judicial hierarchy (Chapter 3, section } 2.1 \text {; Chapter } 4 \text {, section } 4 \text { ). }\end{array}$ \\
\hline Micro level & $\begin{array}{l}\text { Motives of the individual judge: } \\
\text { - legalist (Chapter 2, section 2) } \\
\text { - pragmatist (Chapter 2, section 3) } \\
\text { - personal (Chapter 3, section 2) } \\
\text { - politico-strategic (Chapter 4) }\end{array}$ \\
\hline
\end{tabular}

aligned, allegedly suggesting the matter to be largely clair. The Irish Supreme Court likewise referred James Elliott Construction even though it felt that it could have decided the questions itself and would have reached the same conclusion as the ECJ. The cautious approach of both courts was attributed to past instances in which they had wrongfully not referred or had referred only with great reluctance. The Tax Chamber failed to refer questions that were subsequently referred by the Amsterdam Court of Appeal in Van der Steen. The Irish Supreme Court became more cautious following unanticipated replies by the ECJ in cases in which only a minority had been in favour of a reference: the ECJ adopted a position that diverged from the majority - which had seen no reason to refer - in Grace and Sweetman, Farrell and D.

At the same time, many lawyers still fail to acknowledge that courts are more than robotic legal 'machines' that apply the law in a straightforward fashion. Even the conscientious legal-formalist courts entertain pragmatic considerations, such as the importance of the question and the consequences of referral in terms of delays. Such pragmatic considerations play an important role and the courts in all three countries take them on board, albeit to varying degrees. 
The Dutch highest administrative courts, the UK Supreme Court and the UK and Dutch lower courts are especially pragmatic and reluctant to refer, following a reasonable reading of CILFIT. The Dutch Council of State, for instance, decided not to refer questions about the intensity of review of the credibility assessment of the asylum claim in relation to Article 46(3) of the Asylum Procedures Directive, even though the answer was not clair. Otherwise, a very large number of cases would have had to be put on hold and it would more or less 'have to shut down' the handling of asylum cases. For similar reasons, the Dutch Criminal Chamber decided not to refer questions about the right to legal assistance during a police interrogation. It stated that a reference would preclude 'an effective and expeditious' criminal justice system and would cause a 'long lasting and unacceptable' delay for many cases. ${ }^{2}$ The UK Supreme Court likewise acknowledged that there was no acte clair in the child custody case of $N$ (children), but decided to forgo a reference because the proceedings had 'already taken far too long' and the children's 'best interests demand[ed] that their future should be decided as soon as possible'. ${ }^{3}$

At times, courts - and especially the more pragmatic courts - have also taken into account the expected answers from the ECJ, and have not referred where they believed that they themselves were equally well equipped to answer the question or expected no useful answer from the ECJ. For example, judges of the Dutch Council of State entertained such thoughts in the credibility review case discussed above. They claimed that it would be difficult for the ECJ to examine such a principled issue involving the relationship between the judiciary and the administration. They also wondered whether they would be able to explain the legal problem clearly to the ECJ within the 20-page limit for an order of reference. Similar considerations played a role in HS2 before the UK Supreme Court, which concerned a judicial review of a parliamentary act about a high-speed rail network that had been introduced without an environmental impact assessment.

Chapter 3 highlighted other extra-legal factors and considerations that affect the decision (not) to refer. For example, personal and psychological considerations play an essential role. Three different factors can be discerned in this regard. The first factor is one of the most decisive in terms of the willingness of lower courts to refer - that is, the judge's perspective on the court's judicial role as a court of first or second instance vis-à-vis the highest court(s) and, more broadly, on his or her role in the political system. Dutch lower court judges generally see referral as the task of the highest court(s), given their more limited judicial law-making function and their limited expertise and time.

NL:HR:2015:3608

Re N (Children) [2016] UKSC 15 (Hale), paras 54-55. 
Intermediate courts, such as the Irish Court of Appeal and High Court, are less guided by such considerations and apply a 'better sooner than later' logic. Chapter 3, section 2.1 contrasted Irish High Court referrals in migration cases (HID and $M A$ ) and environmental cases (People over Winds) to resolve the points of law quickly and before a Supreme Court appeal with the reluctance of the Dutch lower courts to avail of the EU preliminary reference procedure. In recent years, the Dutch courts have preferred to refer questions of EU law to the Dutch Supreme Court instead of directly to the ECJ. One example is the social security case of $S F$, involving a Latvian seafarer, in which the questions of the district court were simply passed on by the Supreme Court to the ECJ. Some Dutch lower court judges not only consider referring to be the task of the highest court, but are also of the opinion that the Supreme Court or Council of State is best equipped to refer.

A second personal factor concerns knowledge of EU law and procedure. This is obviously an important prerequisite and a determining factor. However, too much knowledge can also dissuade courts from referring and lead to overconfidence. The latter (partly) explains the reluctance of the UK Supreme Court and the Irish Supreme Court to refer when they had three judges with a Luxembourg background on the bench. The UK Supreme Court is particularly confident in certain areas of law, such as private international and commercial law; the prevailing belief is that the UK sets an example in these areas, while the ECJ lacks sufficient expertise. As a result, the court was generally reluctant to refer in cases where it was sufficiently confident as to the answer that the ECJ would adopt.

A third group of personal and psychological factors concerns the identity, background and attitude of judges. Judges with an academic or governmental background are generally more open to referral than career judges. Feelings of fear and enjoyment may also play a role: some lower court judges are afraid to refer the wrong questions; whereas some enthusiast or activist judges derive satisfaction from engaging with EU law and the ECJ. Examples of the latter are the many references of former Irish High Court and Court of Appeal judge (and current AG) Hogan, such as Schrems, MM and Danqua. UK High Court and (now) Court of Appeal judge Arnold has also made a substantial amount of references in the field of intellectual property law.

There are also three institutional or organizational factors that influence the referral practice of courts and judges: the coordination of EU law cases within a court; the case management system; and the available capacity. Better coordination and more resources obviously favour a reference. One reason for the growing number of references of the Council of State over the past decade was the creation of a committee on EU law and a documentation service that keeps close track of EU law developments. The Den Bosch Court of Appeal made no references in the period 2013-16, but made four references within a six-week 
period in 2012 during which judges were thought to have had more time available to them. By contrast, production targets can be a dissuading factor, as is the case for the Dutch lower courts.

The parties and their lawyers also affect the decision (not) to refer. In more adversarial systems, such as those in the UK and Ireland, courts are unlikely to refer on their own initiative or if the parties are opposed to a referral. By contrast, most of the references of the Dutch highest courts are made without any request of the parties for a referral. One example is the Dutch Supreme Court's reference in De Lange, on whether a tax deduction scheme of study costs for people under the age of 30 conformed with the prohibition against age discrimination in the Equal Treatment Directive (2000/78). Aside from a rather general reference to the prohibition of discrimination in international treaties, no reference to EU law or even the possibility to refer was made by the parties.

Politico-strategic motives should not be discounted too easily, even though much of the social science literature exaggerates their importance. Chapter 4 revealed that such motives play a role in particular areas of law or for some courts. For example, the Dutch Chamber for International Cooperation, dealing with EAWs, has sometimes used the reference procedure as a sword $v i s-\grave{a}-v i s$ the legislature, because it considered several provisions of the Dutch Surrender Act to be in breach of EU law. Chapter 4, section 3 also presented several Dutch migration law references as examples, such as Chakroun, which concerned the minimum wage requirement for family reunification; and $T Q$, on the Dutch return policy for unaccompanied minors. The referring courts called into question overly restrictive migration law and policy through such references.

The shield logic stipulates that courts withhold references from the ECJ in order to prevent Luxembourg from interfering in sensitive political and legal issues. This logic explains several decisions the Dutch Criminal Chamber of the Supreme Court and the UK Supreme Court. Guiding those decisions was a wish to prevent a far-reaching interpretation of EU law that would negatively affect the constitutional set-up or intrude in the national legal system. Chapter 4, section 2 presented several UK examples, including Miller, on Article $50 \mathrm{TEU}$ and UK withdrawal from the EU; Chester, on the voting rights of prisoners; Stott, on the rights of air passengers and the Montreal Convention; and Sanneh, on the rights of residence of third-country nationals with minor children. The Dutch Criminal Chamber's decision not to refer questions on the right to legal assistance during a police interrogation also falls within this category.

Chapter 4 additionally highlighted two other categories of politicostrategically inspired references that have received limited attention in the literature. The first is motivated by a desire to involve the ECJ as a transnational arbiter to resolve particular conflicts or ensure the uniform application 
of EU law. The Tax Chamber of the Dutch Supreme Court preferred to refer customs classification questions, such as in Sonos and Sprengen, even though it already knew the answer itself. This is because a determination by the ECJ has a pan-European effect and guarantees the uniform application of EU law better than a pronouncement by a national court only. Second, some courts have made a reference to highlight particular problems within the ambit of EU legislation and to bring its application to the attention of the ECJ or the EU legislature, such as the SPC Regulation or the EAW system. One good illustration of a reference with a political undertone is Diageo Brands. The Dutch Supreme Court addressed the problem of the limited independence of the judiciary in some Member States and cast doubt on the obligation to automatically enforce a Bulgarian judgment on the basis of the principle of mutual trust.

\subsection{Answer: National Judges' Satisfaction with the ECJ}

The second question considered the views of the referring courts on the ECJ's answers. Chapter 5 examined the assessments of national judges of the procedure leading up to the answer; while Chapter 6 focused on their appraisal of the actual answers. While most judges were generally positive about the ECJ's answers, they were extremely critical of the procedure, as well as some specific answers. Judges did not recognize themselves in the discourse employed by the ECJ, which consistently portrays the preliminary reference procedure as a (horizontal) dialogue or as a cooperative endeavour. In particular, judges in the Netherlands and the UK were critical of the 'ivory tower' mentality of the ECJ. Several problematic features of the procedure - such as the limited involvement of national courts after submission of the referral - were also highlighted.

In addition, most UK and Dutch judges criticized individual judgments. During the interviews, they tended to focus on these outliers, suggesting that one problematic case has a greater impact than several good rulings. Although judges were satisfied with most ECJ judgments, the handful of deficient judgments really stuck in their minds. However, the ECJ cannot be blamed alone for these judgments: the referring court must often shoulder some responsibility for submitting a deficient, vague or incoherent order for reference. Although problematic judgments are in the minority, the interviews revealed that these negative experiences stick in the minds of judges and have a more significant impact on their perceptions than the majority of good ECJ judgments.

Two problems stand out in this regard. The first is the ECJ's inability to answer questions satisfactorily, if at all. One example discussed was Trijber and Harmsen, in which the ECJ failed to answer the Council of State's central and principled question as to whether the Services Directive applies to purely internal situations. Some Council of State judges were equally disappointed 
with the deferential, open answers of the ECJ in $A, B, C$, on the intensity of judicial review of the credibility of the homosexual orientation of asylum seekers. The UK Supreme Court was also critical of gaps in the reasoning of the ECJ and relied on the AG Opinion to fill them in cases such as Patmalniece and Cavendish Square Holding. The ECJ's failure to answer the questions referred sometimes resulted from its (substantive) reformulation of those questions. The ECJ's reformulation in Danqua posed problems for the referring Irish court because the ECJ examined the 15-day time limit for applications for subsidiary (asylum) protection in relation to the principle of equivalence instead of effectiveness, which had never been discussed in the Irish proceedings. UK judges were also critical of the 'disastrous' and 'shambolic' answers in Aimia Coalition. Instead of answering the questions of the House of Lords on the interpretation of the VAT Directive, the ECJ reformulated the questions and examined the VAT treatment of the payments in the particular case.

The second problem concerns the ECJ's failure to appreciate the facts of the case, the national legal framework or the underlying concerns of the referring court. In Franzen, the ECJ wrongly assumed that the referring Dutch tribunal was not obliged to apply the hardship clause in order to remedy unacceptable unfairness. Another exceptional Irish case was the 'long-running drama' of $M M$, which - like Danqua - dealt with the Irish subsidiary protection system. ${ }^{4}$ There was a misunderstanding about the notion of the 'right to a hearing' and whether that required an oral hearing, as is standard practice in common law jurisdictions. Overly factual judgments have proved particularly problematic for the Dutch Supreme Court because facts can no longer be the subject of judicial review at the stage of cassation. The court thus was faced with a challenge when the ECJ diverged from its position in Ladbrokes and Sonos.

\subsection{Follow-up}

Chapter 7 presented an intriguing finding in light of the criticisms of national judges of the preliminary reference procedure and some ECJ judgments. In general, the courts in the three countries studied have diligently - and often almost automatically - complied with the requested ECJ rulings, even in problematic and dissatisfactory cases. They emphasized their strict obligation to follow the ECJ 'even if some of us do not fully understand its reasoning', as the UK Supreme Court held in Patmalniece. ${ }^{5}$ The Irish High Court and Court of Appeal reasoned similarly in $M M$ and Danqua. Despite tremendous frustration, the Dutch Supreme Court held that it could not examine the correctness

MMv Minister for Justice [2018] IESC 10 (O’Donnell J), para 31.

Patmalniece v SSWP [2011] UKSC 11 (Lord Walker), para 73. 
of the ECJ's answer in Diageo Brands. Interviews with judges confirmed this pragmatic approach to follow-up. Even in cases where a change in their own position was required, they generally underlined the importance of full compliance and simply stated that the required change was 'just the way it is' or 'part of the game'.

However, the UK and Dutch courts have avoided full compliance by concluding that they are not bound by a ECJ ruling on the facts, as happened in Aimia Coalition. Another strategy to avoid follow-up is to submit a second reference in order to challenge the earlier ECJ judgment, as happened in the UK migration case of Kaba, the Sunday trading saga in Council of the City of Stoke-on-Trent and Privacy International, which concerned the data retention regime. Most follow-up references had a friendlier, more dialogical character - especially second references by a higher court on points that were not put before the ECJ in the lower court's initial reference. Examples include the Dutch insolvency case of Smallsteps and $M M$, on the right to a hearing in the Irish subsidiary protection procedure. In some cases, a second reference has been made to address the lack of clarity in the first ECJ ruling, as in Visser Vastgoed, after the ECJ failed to consider the applicability of the Services Directive in purely internal situations.

\subsection{Feedback Loops}

The fourth research question in this book concerns whether there is a relationship between the motives of judges (not) to refer and their perceptions of the ECJ and its judgments. Scholars and judges alike have suggested such an intuitively plausible relationship, noting that a judge who feels that he or she has not received helpful guidance might refrain from sending future references to the ECJ. Very few (empirical) studies have considered these feedback loops, not least because of the difficulties in identifying them. National judges were asked about such loops during interviews and generally denied that they play a role in their decisions (not) to refer; although some UK judges acknowledged that previous negative experiences with the ECJ did loom in the background.

Feedback loops can nonetheless be traced by examining two related phenomena which suggest that judges rely on previous experiences or certain expectations in their decision-making process. First, pragmatic courts sometimes take into account the expected answer from the ECJ (Chapter 2, section 3.6). Courts are more reluctant to refer where they expect the ECJ to give very general answers or where they find it difficult to present a complex issue in an order for reference that is limited to the permitted 20 pages. Second, feedback loops are also implicit when courts strategically follow the shield logic and withhold references from the ECJ to prevent an unwanted outcome. Chapter 4 , section 2 demonstrated that frustration over the ECJ's strongly teleological 
approach was a factor in several decisions not to refer, including $H S 2$, on a judicial review of parliamentary acts; Stott, on the Montreal Convention; and Chester, on prisoner voting rights.

It seems safe to say that the reluctance to refer in both types of cases relates to previous experiences with the ECJ. Unlike in the UK, negative feedback loops have not discouraged courts from referring in the Netherlands and in Ireland. On the contrary, one can perhaps discern a positive feedback loop in Ireland: Chapter 6 demonstrated that Irish judges, in particular, are more satisfied with ECJ rulings than their UK and Dutch counterparts, not least because many of the references result in helpful outcome judgments. Previous references of other judges - especially prominent ones such as Schrems and LM/Celmer, on EAW surrender to Poland - also inspired other judges to refer. ${ }^{6}$ Although Dutch judges were critical of the ECJ and some of its judgments, this made them no less inclined to refer future cases. Judges seldom took their previous experiences into account when deciding whether to refer; and the Dutch highest courts have continued to refer despite their criticisms of the procedure and some problematic ECJ judgments.

In the UK, however, the feedback loops seem to operate in the opposite direction compared to Ireland. Arnull suggested that 'a general view of the helpfulness of the procedure based on previous experience' informs the decision on whether to refer. ${ }^{7}$ When this quote was presented to the current UK Supreme Court, however, the suggestion was denied:

The question involves a high degree of speculation. Whilst the Supreme Court has, on occasion, been critical of a lack of clarity in the answers provided by the ECJ, there is no evidence in any of the case law to support the view that such criticism has led the Supreme Court to ignore its obligations under Article 267 TFEU. ${ }^{8}$

That said, the extra-judicial speeches and writings of judges would suggest that the situation is more complex. Lord Mance observed that the "not entirely infrequent uncertainty about what the Court of Justice's answers mean and how to apply them' is a factor that is taken into consideration in the decision (not) to refer. ${ }^{9}$ Likewise, Lord Carnwath suggested in his decision not to refer that no useful answer from the ECJ could be expected, given how it had dealt with previous references. ${ }^{10}$ In interviews, two former UK Supreme

\section{Case C-216/18 LM/Celmer EU:C:2018:586.}

Arnull 2017, 345.

Written response 15 April 2020.

9 Even though he mentioned this in relation to references in gold-plated areas, Mance 2013a, para 11.

10 Oss Group Ltd, $R$ (on the application of) v Environment Agency \& Ors [2007] EWCA Civ 611, para 69. 
Court judges acknowledged that judges might be 'psychologically less eager' to refer, but maintained that this is not a significant factor and plays a role only 'subconsciously'. ${ }^{11}$ One UK barrister likewise attributed the drop in UK references in the last ten years to dissatisfaction with the end product. He/she pointed to dismissive appraisals of judges on the clarity and consistency of ECJ judgments not only in private, but also in open court. ${ }^{12}$ ECJ judgments are not considered to be of high quality and the ECJ is viewed as a 'merits court' that reasons from the facts and is driven by sympathies, especially in the field of social security and citizenship. ${ }^{13}$ This was thought to contrast sharply with the UK courts, which are more focused on black-letter law. However, this critique has not precluded some individual UK judges from referring extensively, despite the disappointing answers received. Former High Court judge Arnold has made a large number of references in the field of intellectual property law, despite being critical of the case law of the ECJ (see Chapter 6).

This warrants the question: what affects these feedback loops - primarily ECJ-related factors, or the motives and attitudes of judges towards referral? Dutch and UK judges are both critical of the ECJ, but the former have not let these negative sentiments influence their decision making; while UK judges have been more critical towards the ECJ and EU law from the outset. This suggests that the (predetermined) attitudes of judges are more important than ECJ-related factors. The question is thus whether it is possible for the ECJ to change the way in which national courts engage with it. To what extent can it prevent courts from following the UK logic of shielding cases from the ECJ because of the expectation that no clarity or an unwanted outcome will follow? It is difficult to give a definitive answer to this question based on the current research, which covers only three countries. Despite this uncertainty, however, the ECJ should nonetheless attempt to improve its engagement with national courts. Section 2 will sketch out several suggestions on how the ECJ can improve that dialogue.

\subsection{Lessons Learned}

The main findings from the three countries studied in this book raise questions as to whether generalizations can be made from them. The book provides a near-exhaustive overview of the motives, considerations and factors that can play a role in the decision (not) to refer, at the different levels of analysis. This is not to say, however, that they all play the same role in every Member State.

\footnotetext{
Interviews 231 and 264, respectively.

Interview 243.

13 Ibid.
} 
Table 8.2 Overview of findings on the motives to refer

\begin{tabular}{lccc}
\hline & Netherlands & Ireland & UK \\
\hline Politico-strategic reasons & & & \\
\hline Shield & $+($ Criminal Chamber of the Supreme & 0 & ++ \\
& Court $)$ & & 0 \\
\hline Sword & + & 0 & 0 \\
\hline Leapfrogging & + & 0 & + \\
\hline Transnational arbiter & ++ & + & + \\
\hline Agenda setting & + & + & - \\
\hline Non-political considerations & & & ++ \\
\hline Legal formalism & $+($ Civil and Tax Chambers of the & ++ & ++ \\
& Supreme Court) & & + \\
\hline Pragmatism & ++ & ++ & ++ \\
\hline $\begin{array}{l}\text { Personal and } \\
\text { psychological }\end{array}$ & ++ & & + \\
\hline Institutional & & + & \\
\hline Role of the parties & + & & + \\
\hline
\end{tabular}

The exhaustiveness of this myriad of motives stems from the book's combined deductive and inductive approach. It relies heavily on both theoretical and empirical studies, which means that it has included all factors previously discussed in the literature. Its inductive nature has been used as a safety valve. Open-ended interviews allowed national judges and other interviewees to propose motives that have not featured prominently in the literature thus far, such as the two politico-strategic considerations relating to agenda setting and the role of the ECJ as transnational arbiter.

No generalizations can be made on the extent to which these different motives, considerations and factors play out in practice. As Table 8.2 shows, the three Member States score differently in this regard; and even within the individual Member States themselves, there is considerable divergence between and within courts. Particular factors also play a more or less significant role in other Member States. Chapter 3 revealed that fears about potential negative career prospects played almost no role in the three countries studied; whereas Slovenian and Croatian judges do consider this possibility.$^{14}$ Hence, for example, particular motives could play a different role in more judicially centralized states, where the recruitment, appointment and promotion of judges are organized at a central level; or in states that lack a culture of judicial

14 Leijon and Glavina 2020. 
review, such as the Scandinavian countries. ${ }^{15}$ The dynamic can be even more different in Member States where the rule of law is backsliding and where judges refer out of self-defence, in order to protect their constitutional position and judicial independence. ${ }^{16}$ It seems that although the Netherlands diverges from Ireland and the UK in the sense that it is a civil law country, the three countries share an important underlying feature: the relatively independent position of courts and judges in relation to politics and the wider judiciary. Macro-level factors should thus not be neglected. These factors also affect the variables at the meso and micro levels of analysis.

It would seem further that generalizations can be drawn beyond the three countries studied from the findings on the satisfaction of national judges with the ECJ and follow-up. They confirm the findings of older studies that revealed high rates of implementation and support the widely shared belief that ECJ judgments are generally accepted and followed. ${ }^{17}$ This means that instances of non-compliance in other EU Member States - such as Weiss, Billerud, Dansk Industri and Landtová - are exceptions that prove the rule. However, the limited number of such cases should not be taken as an indication that the preliminary reference procedure is functioning optimally, as is especially illustrated by the discontent expressed by national judges in Chapters 5 and 6 . Recent (empirical) research suggests that their critical views on the quality of dialogue with the ECJ and its judgments are shared by courts in other Member States. ${ }^{18}$ In order to avoid a repeat of the situation in the UK, where negative feedback loops have played a role in recent years (section 1.4), steps should be taken to improve this interaction (section 2).

The findings also have theoretical and empirical implications. Theoretically, this book shows that multiple theoretical perspectives account for the decisions of courts to refer and the total number of references from each Member State. There is no single explanation for the referral practice in a particular Member State. This multi-causal nature explains the variations among and within Member States, both over time and across policy areas (see Table 8.2). ${ }^{19}$ This finding is hardly surprising as such, but is worth emphasizing in light of the scholarly literature, which often tries to single out one key factor. The findings also support the importance of a nuanced approach which leaves room for the

\footnotetext{
15 Wind 2010.

16 Case C-487/19 WŻ (Chambre de contrôle extraordinaire de la Cour suprêmeNomination); Case C-508/19 Prokurator Generalny (Chambre disciplinaire de la Cour suprême - Nomination); Jaremba 2020.

17 Schwarze 1988; Korte 1991; Meij 1993; Wils 1993; Weiler 2013, 235.

18 Van Gestel and de Poorter 2019.

19 Stone Sweet 2004, 240; Carrubba and Murrah 2005, 414; Alter 2002; Stone
} Sweet 2010, 31. 
operation of several theories and perspectives at the same time. The findings downplay the role of politico-strategic motives, which have dominated the early social and political science literature in particular. They also show that legal formalist reasons, which have often been overlooked by social and political scientists, should be given due consideration. What is more, the book corroborates that the recent emphasis on the micro level and the individual agency of judges is justified and deserves further attention. ${ }^{20}$

Empirically, the book demonstrates that the mere examination of judgments alone is not enough to appreciate what is really going on in terms of the actual motives of national court judges to refer and their appraisal of the dialogue with and judgments of the ECJ. Semi-structured interviews with judges, AGs and law clerks revealed the true thoughts of judicial decision makers in this regard. Mere reliance on follow-up judgments gives a false impression that the dialogue or interaction is functioning optionally, because national courts almost always comply fully and automatically with ECJ judgments. This relatively straightforward follow-up camouflages their dissatisfaction with their interaction with the ECJ and the quality of some ECJ judgments. As will be argued in section 2, it is of utmost importance for the functioning of the preliminary reference procedure in the EU legal order that these concerns be addressed.

\section{THE WAY FORWARD: IMPROVING INTERACTION WITH THE ECJ}

Chapters 6 and 7 revealed an urgent need for improvement in two regards. First, there is a need to improve the quality of interaction between the ECJ and national courts and strengthen the dialogical features of the preliminary reference procedure. The findings confirm the allegations raised in the introductory chapter that both the ECJ and the procedure have come under significant pressure in recent years. Recent (empirical) studies likewise suggest that the legitimacy of the ECJ is 'more fragile and contested' and rests on a 'very thin basis' ${ }^{21}$ The research of van Gestel and de Poorter in particular demonstrates the importance of improving the dialogical features of the procedure in order to avoid non-compliance and to maintain the legitimacy of ECJ judgments. ${ }^{22}$ The findings in Chapters 5 and 6 underscore the need to involve the referring 
court once the reference has been made. ${ }^{23}$ Dutch judge and academic de Werd also argued that not allowing the national judge to intervene in the event of misunderstandings 'is a missed opportunity in terms of the efficiency and effectiveness' of the procedure. ${ }^{24}$ Bobek likewise noted the 'pedagogical and legitimacy-enhancing' advantages to be gained should national courts obtain a 'direct voice and participation' in the procedure. ${ }^{25}$ A second related aspect is the workload of the ECJ. While its docket continues to grow each year, the ECJ has managed to keep the average duration of proceedings to an acceptable level (15.5 months at the time of writing) - albeit not without consequences for the quality of the reasoning in its judgments, as noted both by scholars and by the judges interviewed (Chapter 6) ${ }^{26}$ There are thus grounds for both the ECJ and the national courts to adjust the way in which they currently operate in the context of the preliminary ruling procedure.

\subsection{Suggestions for the ECJ: Clarification Requests, CILFIT 2.0 and Specialization}

First, the ECJ should overcome its reluctance to seek clarification from the referring court where necessary. ${ }^{27}$ Article 101 of the Rules of Procedure allows the ECJ to ask for additional information on the purpose of particular questions, the national legal framework or the facts of the case. The ECJ could even consult the referring court where it reformulates the questions in such a way that changes their content. ${ }^{28}$ Irish Supreme Court judges brought this issue to the attention of the ECJ during a bilateral meeting with ECJ judges, because the recasting of questions is considered to do more harm than good, as discussed in Chapter 6 , section 2.3. Fears that this could result in significant delays because some national systems would require the courts to hear the parties' views on the request should not be over-exaggerated. ${ }^{29}$ The ECJ should also examine whether it can creatively deal with the perceived need and associated costs - of translating the clarifications of the national court. To

23 A considerable number of supreme administrative courts recognized the benefits of 'alternative forms of communication' after the reference and before the ECJ judgement. Van de Gronden et al 2016, 14.

24 De Werd 2015b, 153.

25 Bobek 2013b, 212-13.

26 ECJ annual report 2019, 15; Bobek 2020, 87; Sharpston 2014, 765; Weiler 2013, 235; Jacobs et al 2019, 1216.

27 The ECJ has done this on an average of seven times on an annual basis. In the 7.5 years between 1 January 2009 and 30 April 2016, this happened in 56 cases; van de Gronden et al 2016, 29. Cf Langer 2015, 15; van Gestel and de Poorter 2019, 84.

28 Van Gestel and de Poorter 2019, 127.

29 Van de Gronden et al 2016, 29. 
what extent is it truly necessary to translate everything, as Article 101(2) of the Rules of Procedure seems to suggest? ${ }^{30}$

Second, the ECJ should seek to explain more clearly its treatment of the arguments of the national courts, especially where it deviates from certain assumptions, preferred interpretations or provisional answers. ${ }^{31}$ The same applies in situations in which the ECJ diverges from the approach of the AG or from earlier decisions. ${ }^{32}$ As shown recently by de Búrca, the ECJ acknowledged that it had considered the referring court's view in just four of the 46 references made by the UK higher courts. She argues that, given the increasing scepticism towards the ECJ, there is more reason than ever for it to be more responsive and practise what it preaches in terms of dialogue. ${ }^{33}$

Third, the ECJ should relax the CILFIT requirements and should not be afraid to issue a 'CILFIT 2.0' that reflects the current realities on the ground. It is often lamented that it is more difficult to conduct a CILFIT assessment in today's EU, with 27 Member States and 24 official working languages, than when CILFIT was rendered in 1982, when the EU had just ten Member States and seven working languages. How can a national court be convinced that a particular interpretation is 'equally obvious' to courts in (all, most or only a couple of) Member States, and to the ECJ? It is unsurprising that AG Wahl noted: 'If one were to adhere to a rigid reading of the case-law, coming across a "true" acte clair situation would, at best, seem just as likely as encountering a unicorn.' ${ }^{34}$ Chapter 2, section 3.2 showed that the Dutch highest administrative courts and the UK Supreme court have adopted a pragmatic reading of CILFIT. In particular, the UK Supreme Court has reserved the right to apply established principles itself to new cases. The Dutch Council of State, and more recently the Tax and Civil Chambers of the Dutch Supreme Court, have also taken a more proactive and autonomous stance, and given themselves room for a more independent interpretation of EU law (Chapter 2, section 3.6). ${ }^{35}$ The Council, for instance, applied different interpretation methods in line with the CILFIT requirements in a structured and transparent way. ${ }^{36}$ There should be room for this approach in cases where there is already some ECJ jurisprudence.

\footnotetext{
$30 \quad$ Ibid.

31 Arnold 2020, 1105-06; van Gestel and de Poorter 2019, 18.

32 Harris 2008, 376-77.

33 De Búrca 2020.

34 AG Wahl in Joined Cases C-72/14 and C-197/14 X and Van Dijk EU:C:2015:

319 , para 62.

35 Becton v Braun NL:HR:2018:721; NL:HR:2018:862.

36 Eg NL:RVS:2019:2486, para 4; Stichting Greenpeace Nederland v Minister van LNV NL:RVS:2020:2571, para 7.2.1.
} 
Giving more room to national courts to act as co-interpreters would reflect the maturity of the EU legal order and recognize that the ECJ does not have exclusive expertise over all areas of EU law across a diverse array of policy fields, which often involve complex, sensitive and political choices. ${ }^{37}$ There is especially reason to broaden the role of national courts in relation to the 'factual jurisprudence' of the ECJ, dealing with the application of the established principles of EU law to new cases (Chapter 2, section 3.2 and Chapter 6 , section 2.4). Bobek criticized the 'factual jurisprudence' of the ECJ and the court's implicit desire to have the last word in every single application of a legal interpretation by national courts. He held that the ECJ should accept some diversity in this regard and called on the ECJ to revisit CILFIT. ${ }^{38}$ This mirrors AG Jacobs' call for 'self-restraint' in his Opinion in Wiener. He cautioned against national courts referring for 'further clarification' when the facts of cases differ (only slightly) from those in which the ECJ had answered similar questions. ${ }^{39}$ There is also a more pragmatic argument for relaxing CILFIT with respect to the application of established principles to new cases namely, the ever-expanding workload of the ECJ.

Admittedly, relaxing CILFIT could have consequences for the uniform application of EU law in Member States. However, complete uniformity is a fiction, just like a true acte clair. Dougan noted recently that:

it is surely misleading to speak of Union law as if it were a single and uniform being: there are in fact 28 versions of EU law - that of the Union legal order and those constructed within each and every Member State. ${ }^{40}$

The losses that might result from a more relaxed CILFIT standard are thus smaller than the gains - namely, alleviating the burden on the ECJ so that it can concentrate on the difficult cases and improve its reasoning with a view to enhancing the dialogical features of its judgments. Sufficient checks are in place to empower natural and legal persons, and the European Commission, to monitor national courts' compliance with their obligations under Article 267 TFEU, and to prevent or act upon at least the most egregious breaches. These enforcement mechanisms exist both at the domestic level (Köbler), the EU level (infringement procedures) and the ECHR level (complaints to Strasbourg) (Chapter 1, section 2). 
Fourth, if the ECJ's case docket continues to grow and eventually becomes unmanageable, more far-ranging structural measures may be needed. With a more sizeable General Court, the option of transferring part of the jurisdiction over preliminary references to the General Court in line with Article 256(3) TFEU could (again) be put on the table, despite the reluctance of the ECJ and EU Member States to pursue this option..$^{41}$ Legal and policy areas such as customs, VAT and trademarks are often mentioned as suitable candidates for transfer to the General Court. ${ }^{42}$ Another related measure that could help to reduce the ECJ's workload by increasing the efficiency of case handling is the creation of specialized chambers. This would facilitate the systematic development of the law and thus enhance consistency and legal certainty, while also facilitating more extensive legal reasoning. Such specialization could be particularly valuable in the areas that have been the focus of criticism from national judges, such as tax law, private international law and trademark and patent law (Chapter 6, section 2.4). ${ }^{43}$

\subsection{Suggestions for National Courts: Better Referrals, Provisional Answers and Follow-up References}

Chapter 6 argued that it is unfair to blame the ECJ exclusively for problematic judgments in which it fails to answer the questions satisfactorily or in which it misunderstands the facts, the national legal framework or the underlying concerns of the referring court. Part of the responsibility for deficient answers must lie with the referring court and its order for reference - including questions that are ill formulated, too implicit or too general. General or unclear questions often lead to general or vague answers. In addition, a suboptimal answer may result from an insufficient or minimal description of the national legal framework, the central issues and the relevant facts. The analysis of problematic judgments would thus lead to the following recommendations for referring courts. They are far from revolutionary, because most of them are addressed in the recommendations drafted by the ECJ for national courts. ${ }^{44}$ However, as the previous chapters have shown, not all orders for reference meet these recommendations. Implicit in these suggestions is the notion that the referring national court must remember that the ECJ lacks 'inside information'

41 Leppo 2020, 7; Report of the Court of Justice on possible changes to the distribution of competence for preliminary rulings under Article 267 TFEU, 15995/17, 21 December 2017.

42 Leppo 2020, 8.

43 Arnold 2020, 1105; Jacobs et al 2019, 1222; Harris 2008.

44 Cf 2019/C 380/01 Recommendations to national courts and tribunals in relation to the initiation of preliminary ruling proceedings. 
about both the case and the applicable national law. The order for reference should thus provide sufficient context and all necessary details about the national legal framework and the facts of the case. It is also essential that the referring court clearly explains why the questions are relevant and how they contribute to the resolution of the dispute. In addition, to facilitate the translation of the order for reference into all other official languages, the referring court should use simple language; clearly distinguish between the most relevant parts of its decision and more minor points; and avoid expressions that are difficult to translate. ${ }^{45}$ It is further worth emphasizing the following additional suggestions.

First, the referring court should clearly consider the purpose of the reference and make this explicit in its request for a preliminary ruling. ${ }^{46}$ This book has underlined the usefulness of the preliminary reference procedure: it not only helps the referring court to resolve difficult disputes and complex legal puzzles, but can also empower the court to actively influence the development of EU law or put a particular issue on the political or legislative agenda. In doing so, the referring court can push the ECJ in a desired direction that also fits with the national legal order ${ }^{47}$ In responding to the reference, the ECJ can also offer the national court a helping hand $v i s$-à-vis its national legislature, executive or other courts in the same or another Member State.

The purpose of a reference also affects the structure of the order for reference. If the purpose of the referral is to inform or to verify, and to obtain legal clarity, a neutral exposition of the factual and legal context may suffice. However, if the reference has a different purpose - such as voicing criticisms on particular legal issues or earlier ECJ case law, or setting the political or legislative agenda - the order for reference should take a more discursive form and should be well reasoned and convincing. This difference is also important in shaping the judgment of the ECJ and in determining the extent to which the ECJ should take into account the views of the referring court and its response to those views. The findings in Chapter 6 suggest that one of the most frustrating results of a reference is a feeling that the ECJ did not take the concerns of the referring court seriously. The more explicit the referring court is about the purpose of the reference and what it expects the ECJ to address, the greater the chance of that being realized. This is especially so where courts refer a relatively easy question that is (almost) clair. The ECJ generally disposes of such case without an AG Opinion and in a three-judge composition.

\footnotetext{
Coumans 2017.

Cf Arnold 2020, 1105.

Langer 2019; Rytter and Wind 2011.
} 
In doing so, however, it could miss the implicit objective of the referring court, as happened in Diageo Brands.

Second, the consequences of a particular interpretation should be sketched out more forcefully. This concerns not only the implications for the legal framework or the judicial system, but also wider societal, political or financial implications. One good Dutch example is Massar, in which the Supreme Court sketched out the considerable financial consequences that would ensue if the ECJ were to find that the EU Directive on legal expenses insurance also applied to more administrative procedures before the Employee Insurance Agency. ${ }^{48}$

Third, referring courts should also be more upfront in providing a provisional answer. The ECJ encourages national courts to do so in Article 107(2) of the Rules of Procedure, as well as in its recommendations. However, very few courts actually provide a genuine provisional answer in the form of a ready-made dictum. ${ }^{49}$ Providing a provisional answer is attractive where the court is referring for politico-strategic reasons. The Dutch Supreme Court could easily have done this in Massar, but judges are generally reluctant to do so out of caution and the fear of getting 'a clip around the ear' ${ }^{50} \mathrm{~A}$ provisional answer seems particularly warranted in cases where the national court refers simply to have the ECJ confirm what it could have determined itself - for example, in relatively easy customs tariff cases in which an authoritative determination of the ECJ is sought to guarantee the uniform application of EU law. The use of provisional answers in this way, which would enable the ECJ to dispose of the case relatively easily, mirrors the 'green light procedure' proposed by former AG Jacobs, among others. ${ }^{51}$

Fourth, national courts should not hesitate to submit follow-up questions where an answer is unclear or missing, or where they disagree with the ECJ's judgment. It is understandable that courts are reluctant to go back to Luxembourg, especially from the perspective of the parties and the resulting delays that will ensue from a second reference; but where the case lends itself to re-referral or where a new case involving similar problems arises, national courts should not 'turn off', but should rather engage with the ECJ again. The repeated questions of the Dutch Council of State on the applicability of the Services Directive in purely internal situations (Trijber and Harmsen and later Visser Vastgoed) show that the underlying concerns were taken seriously after the second reference: when the case was brought to Luxembourg for a second

Case C-460/14 Massar EU:C:2016:216.

49 The Minister for Justice, Equality and Law Reform v RO No 4 [2018] IEHC 284;

Case C-327/18 PPU R O EU:C:2018:733.

$50 \quad$ Interviews 45, 75 and 87.

51 Meij 2004; Jacobs 2004; Jacobs 2014. 
time, a Grand Chamber formation addressed the questions head-on. Something similar happened when the Italian Constitutional Court submitted the Taricco case once again; the Constitutional Court gave the ECJ a chance to reconsider the priority it had afforded to the obligation to effectively tackle VAT fraud (Article 325 TFEU) over the principle of legality enshrined in Article 25(II) of the Italian Constitution. ${ }^{52}$ Another recent example is the Grand Chamber judgment issued after the Belgian Council invited it to reconsider its consistent line of case law in relation to the concept of 'plans and programmes' in the Environmental Impact Assessment Directive. ${ }^{53}$ One option for the ECJ is to fast-track follow-up references in a similar way to the French preliminary ruling system, which provides for a service-après-vente - namely, the possibility to ask the French Council of State for a clarification of its judgment. ${ }^{54}$

Joined Cases C-360/15 and C-31/16 X and Visser Vastgoed EU:C:2018:44; Case C-42/17 MAS and MB EU:C:2017:936.

53 Case C-24/19 A and Others EU:C:2020:503, para 29. 140.

54 R 931-1 of the Code de justice administrative; van Gestel and de Poorter 2019, 